\title{
THE ORIGIN OF THE NEGOTIABLE PROMISSORY NOTE
}

\section{Jacob J. Rabinowitz $\dagger$}

The origin of the negotiable promissory note has been widely discussed by legal historians. Brunner, who has devoted a number of articles to the subject, ${ }^{1}$ maintains that the principles underlying the negotiable promissory note are traceable to Germanic law and that the main elements of the negotiability clause are discernible in Lombard documents of the eighth, ninth and tenth centuries. ${ }^{2}$ Under the Germanic law of procedure, Brunner asserts, the emphasis was upon the validity or invalidity of the defendant's defense and not upon the validity of the plaintiff's claim. In other words, it was incumbent upon the defendant to show why he was not liable to the plaintiff. Therefore, he says, when the promise ran to the person in whose hands the instrument would appear, the defendant had no valid defense against the holder of the instrument who was not required to show how the defendant became liable to him. ${ }^{3}$

It seems, however, that Brunner's so-called "principle of the Germanic law of procedure," which supposedly lays stress upon the validity of the defendant's defense-a most peculiar principle indeed-is but a product of his own imagination. He cites no evidence whatsoever for this principle, except the facts which he seeks to explain by it. Furthermore, Brunner would apparently have us believe that the spirit of the Germanic law of procedure, having asserted itself through the LomYork Bar.

† Professor of Law, The Hebrew University, Jerusalem. Member of the New

1. See the following articles by Brunner: Das franzoesiche Inhaberpapier des Mittelaters, in FESSCHRIFT FUER H. THOEL 7 (Germany 1879), reprinted in 1 BRUNNER, ABHANDLUNGeN zUR RechtsGesceichte 458 (1931); Carta und Notitia, in CoMsMentationes philologicae IN HONOREM TH. MoMmsenI 570 (1877), reprinted in 1 BRUNNER, op. cit. supra at 458; Zur Geschichte des Inhaberpapiers in Dentschland, 23 ZEITSCHRIFT F. D. GES. HANDELSRECHT [hereinafter ZEITSCHRIFT] 225 (Germany 1878); Die Fraenkisch-romanische Urkunde, 22 ZEITSCHRIFT 59, 105 (Germany 1877).

2. Brunner, Die fraenkisch-romanische Urkunde, 22 ZEITSCHRIFT 59, 105 (Germany 1877). Brunner's theory of the origin of negotiable instruments is followed by Jenks, The Early History of Negotiable Instruments, in 3 SELECT ESSAYS IN ANGLOAMERICAN LEGAL HISTORY 51 (1909) and by Holdsworth, The Origin and Early History of Negotiable Instrunents, 31 L.Q. REv. 12 (1915). at 20 .

3. 1 BRuNnER, op. cit. supra note 1, at 539-40. See also Holdsworth, supra note 2, 
bard notaries of the eighth, ninth and tenth centuries, lay dormant for about three centuries until it came back to life again in the French, bearer instruments of the early fourteenth century.

The theory of the Germanic origin of the negotiable promissory note has been effectively refuted by Freundt. ${ }^{4}$ He has shown that the clauses in the Lombard documents, mostly deeds of conveyance, which Brunner considered the prototypes of the negotiable promissory note, have nothing to do with negotiability. Of late it has been recognized by historians of English law that at least in England in the thirteenth century the Jews played an important part in the development of the negotiable promissory note. ${ }^{5}$ But the full story of the origin of this legal device still remains to be told.

\section{The Negotiable Promissory Note with the Order Clause}

The forerunner of order paper, in the form of a promise to pay to a named individual or to "your messenger" (vel certo muncio tuo or misso tuo), begins to appear regularly in Genoa about the middle of the twelfth century. ${ }^{6}$ Brunner correctly points out that the term muncius in these documents does not mean just a messenger (bote). ${ }^{7}$ The nuncius was a true agent vested with authority to settle or compromise the claim on behalf of the principal. The appointment of a nuncius was a formal act requiring the preparation of a notarial document. Brunner cites such a document from Italy, dated 1156, which reads in part as follows: Ego Solimamus facio te Ogerius de Ripa nuncium meum ad recuperandum tarenos 1255 . . . quos mihi debet Jordanus de Molino. ${ }^{8}$

4. 2 Freundt, Wertpapiere IM ANTIKEN UND FRUEMitTELALTERICHEN RECHTE 76-121 (1910).

5. Beute1, The Development of Negotiable Instruments in Early English Law, 51 HARv. L. REv. 813 (1938). See also Bailey, Assignment of Debts in England from the Trelfth to the Twentieth Century, 47 L.Q. Rev. 516, 534 (1931). The theory that the negotiable instrument is of Jewish origin was first advanced by Auerbach. See Auerbach, Das Juedische Obligationsrechr 250-58, 270-90 (1871). He was, however, unable to draw upon the documentary material, particularly from Anglo-Jewish and Spanish-Jewish sources, which has since become available. Also, his assertion that the negotiable instrument was known and used by the Jews in talmudic times seems to be without support in the Talmud. While it is true that the legal principle upon which Jewish authorities of the later Middle Ages based the validity of negotiable instruments is found in the Talmud, it does not seem that this principle was made use of until the later Middle Ages.

6. See, e.g., 1 II Cartolare di Giovanni Scriba 3, 10 (Documenti e Studi per la Storia del Commercia e del Dirito Commerciale Italiano no. 1, 1935) (documents used in 1155); id. 28, 34, 62 (documents used in 1156); id. 28, 411, 414 (documents used in 1160).

7. "Der nuncius, message, ist in diesen Urkunden nicht als ein blosser Bote, sondern gleich dem procureur als ein Befollmaechtigter aufzufassen, der quittieren und klagen darf." I BRUNNER, op. cit. supra note 1, at 554.

8. 1 Il Cartolare di Giovanni Scriba 59 (Documenti e Studi per la Storia del Commercia e Del dirito Commerciale Italiano no. 1, 1935) (document used in 1156). 
The vel certo nuncio tuo clause also occurs in twelfth century documents from Constantinople ${ }^{\theta}$ and from Venice. ${ }^{10}$ In Marseilles ${ }^{11}$ it is found in the first half of the thirteenth century, and in England ${ }^{12}$ it appears in the second half of the same century. The term nuncius is also used in England in the thirteenth century in connection with several transactions involving the assignment of bonds by Jews, where the assignee is referred to as the Jew's nuncius. ${ }^{13}$

The question arises how did the word nuncius, which in its original sense denotes a mere messenger, come to mean an agent vested with authority to act on behalf of the principal, or even an assignee who acts in his own behalf? This question becomes still more pointed when we bear in mind that the Latin term most approximating that of agent for the collection of a debt is procurator. Indeed, in thirteenth century instruments for the appointment of agents we find that while the term muncius is still retained, the term procurator is added. ${ }^{14}$

The answer to the above question is that the origin of the documents using the term nuncius in the sense of agent is Jewish. There is only one word in Hebrew for both messenger and agent. The word is shaliah, which is derived from the verb shaloah (to send). The difference between the noun shaliah in the sense of messenger and the same noun in the sense of agent can only be gathered from the verb which is used in connection with this noun. A shaliah-messenger is sent (shalah shaliah); a shaliah-agent is made (asah shaliah). In the legal literature of the Jews the term shaliah usually means an agent. Thus, the part of Maimonides' Code which deals with agency and partnership is called Hilkot Sheluhin Ve-Shutafin-The Laws of Agents and Partners.

The messenger (shaliah) or the representative (ba-koah) of the creditor is referred to in some of the forms in the formulary of $R$. Judah Barzillai (eleventh century, Spain)..$^{15}$ In a Hebrew bond from Barcelona, dated 1112 and made by a Jew to a non-Jew, the debtor undertakes to pay to the creditor or to his representative $(b a-k o a h) .{ }^{16}$

9. 7 ARCHivio VenEto 97-98 (Italy 1874) (document used in 1148).

10. $7 \mathrm{id}$. at 149-50 (document used in 1168).

11. See, e.g., 1 Blancard, Documents inedits sur le Commerce de Marseilles $12,38,48,52$ (1884).

12. See 2 Pollock and Mattland, History of English Law 227 (2d ed. 1899).

13. See 1 Calendar of The Plea Rolis of the Exchequer of The Jews 223 (Rigg ed. 1905) (1218-72); 2 id. at 255 (Rigg ed. 1910) (1273-75).

14. See, e.g., 6 Historiae Patriae Monumenta col. 1356 (1836) (document used in 1228); 6 id. col. 1479 (document used in 1248); 1 BLANCARD, op. cit. supra note 11 , at 60 (document used in 1234).

15. R. Judar Barzillai, Sefer Ha-ShTaroth (Formulary) nos. 7, 14, 34, 42 (Halberstam ed., Berlin 1898).

16. VAletcrosa, Documents Hebraica DE JUEUs Catalans no. 21 (Institut d'Estudis catalans, Memories, vol. 1, fasc. 3 1927). 
The Jews, who had occasion to use Latin documents in their dealings with Christians, simply translated the word shaliah, which in its original sense means messenger, by the Latin word muncius or missus having the same meaning. Christians followed the example set by the Jews. So much so that in the twelfth century they used the phrase facio nuncium-I make an agent-which corresponds to the Hebrew oseh shaliah. Even in the thirteenth century, when Italian and French notaries had become familiar with Roman legal terms, those arch-conservatives still retained the terms facio and nuncius, though they added the words constituo and ordino to the former and the word procurator to the latter. ${ }^{17}$

In addition to the term muncius or missus, the documents containing the vel certo nuncio tuo clause reveal several other marks of Jewish influence. We shall list these seriatim.

1. The documents from Genoa ${ }^{18}$ and those from Marseilles ${ }^{19}$ are framed in the form of an acknowledgment (recognizance) of the debt by the debtor. In the Genoa documents it is the word profiteor or confiteor (I profess or confess) that is used; in most of the Marseilles documents it is the phrase profiteor et recognosco ${ }^{20}$ (I profess and acknowledge) and in some profiteor et in veritate recognosco (I profess and in truth acknowledge). It is the last phrase which betrays the Jewish origin of the form. This phrase is an adaptation of the Hebrew modeh hodaah gemurah (acknowledge a true acknowledgment). As the writer has shown elsewhere, ${ }^{21}$ the Hebrew phrase, which is translated in a thirteenth century document from England as recognosco veram recognitionem, ${ }^{22}$ grew out of certain rules of Jewish law with regard to the validity of recognizances.

2. The Genoa, Constantinople, Venice and Marseilles documents contain a provision for a general lien upon the obligor's property in

17. See documents cited in note 14 supra.

18. See documents cited in note 6 supra.

19. See documents cited in note 11 supra.

20. See 1 BILANCARn, op. cit. supra note 11, at 62-74. In a Spanish document of 1226 (BAER, DIE JUDEN IM CHRISTLICHEN SPANIEN 85-86 (1929)), representing an acquittance made by a Jew, the same phrase occurs. In a number of twelfth century acquittances from Montpelier the following variations of this phrase occur: "Scio et vero cognosco"-IIBER INSTRUMEnTORUM MEMORALIUM, CARTULAIRE DES GUILEMO DE MONTPEITER 329 (1884) (document used in 1165); "Scio et in veritate cognosco et assero"-id. at 332-33 (document used in 1196-1197); "Scio et in veritate cum hac carta cognosco"-id. at 344 (document used in 1200); "Scimus et in veritate cum hac carta cognoscimus et profitemur"-id. at 156 (document used in 1142).

21. See Rabinowitz, The Influence of Jezeish Law on the Development of English Law, in 1 The Jews: TheIr History, Culture and Reitgion 501-02 (Finkelstein ed. 1949).

22. 1 Abrahams, Stokes and Loewe, Starrs and Jewish Charters in the BrITISH MUSEUM 4-5 (1930) (document used in 1234). 
favor of the obligee, which has been a regular feature of the Jewish writing obligatory since talmudic times and possibly earlier.

In the Constantinople and Venice documents the clause providing for a general lien on the obligor's property contains a quaint phrase which betrays the Jewish origin of the clause. The obligor binds "all his lands and houses and all his property in this world" for the performance of his obligation. In the Constantinople document, dated 1148, the clause in question reads:

"hec que suprascripta sunt si tibi non observavero tunc emendare debeam cum meis heredibus, tibi et tuis heredibus omnia tua suprascripta in duplum de terris et casis meis, et de omnibus que habere visus fuero in hoc seculo." 23

In the document from Venice, dated 1168, the obligor's afteracquired property is included within the scope of the lien, the clause reading: ". . . de omnibus que nunc habeo vel in antea habere debeo in hoc seculo." 24 In another document from Venice, dated 1173, the clause in question reads: ". . . que nunc habemus aut in antea habituri sumus in hoc seculo." 25 In the Jewish form of the writing obligatory, for example in the formulary of Rab Hai Gaon (ca. 1000), the obligor binds all property which he has and which he may acquire in the future under heaven. ${ }^{28}$

3. The documents from Genoa contain a provision in which the creditor is empowered, in case of default by the debtor, to enter upon the debtor's property and obtain satisfaction of the debt therefrom. This provision too is a regular feature of the Jewish writing obligatory of the Middle Ages. ${ }^{27}$

4. The documents from Marseilles ${ }^{28}$ contain a clause in which the debtor undertakes that in case of default in payment he is to pay to the creditor the damages he may have suffered and the expenses he may have incurred by reason of such default, and to the extent

23. 7 Archivio Venero 97-98 (Italy 1874).

24. 7 id. at $149-50$.

25. 8 id. at $149-50$.

26. Rab Hai Gaon, Sefer Ha-shtaroth (Formulary) no. 4 (Asaf ed.) published in 1 TARBITZ (publication of the Hebrew University of Jerusalem) (Supp. 1930). See also Rab Saadiah Gaon, Sefer Ha-shtaroth, published in SAADIA 72 (Fishman ed., Jerusalem 1942). It is interesting to note that the phrase all things under heaven also occurs in some Constantinople and Venice releases, where the party executing the release states: "Et nichil inde remansit de ulla re de sub celo." 7 ARCHIVo VENETO 95 (Italy 1874) (document used in Constantinople in 1147); 8 id. at 138 (document used in Venice in 1161).

27. See Rabinowitz, Jezrish and Lombard Law, 12 Jewrse Social Studies 320 (1951).

28. See, e.g., 1 BLANCARD, op. cit. supra note 11, at 38, 48, 52, 75. 
of such damages and expenses the creditor shall be believed on his simple word. As the writer has shown elsewhere, ${ }^{29}$ a similar clause is found in Jewish documents considerably earlier and is based upon a principle of Jewish law going back to talmudic times.

5. In some of the documents containing the vel certo nuncio tuo clause, the coin in which the debt is payable is described as boni et justi ponderis-good and of correct weight. ${ }^{30}$ This description of the $\operatorname{coin}^{31}$ is a regular feature of Jewish bonds throughout the Middle Ages and is also found in the Babylonian Talmud ${ }^{32}$ in the name of a third century authority.

All of the above, in its cumulative effect, leads to the conclusion that the vel certo nuncio tuo clause is of Jewish origin. We shall now turn our attention to the alternative bearer clause.

\section{The Promissory Note with the Alternative Bearer Clause}

The vel certo muncio tuo clause was undoubtedly an important step towards achieving negotiability. The debtor who bound himself in advance to pay the creditor's agent could not refuse to recognize the right of the holder of the note, who was the creditor's agent, to demand payment. But this clause did not achieve true negotiability, the essence of which is that the holder of the instrument may demand payment in his own right. True negotiability was only achieved by the clause in which the maker bound himself to a named individual or to the bearer of the note. Under this clause, the holder of the note was just as much entitled to demand payment in his own right as the party named therein.

The earliest French note with an alternative bearer clauseà $N$, ou à qui cette lettre portera-cited by Brunner, is dated $1291 . .^{88}$ But evidence of the use of the alternative bearer clause by Jews in notes written in Hebrew is found considerably earlier. As already noted by Beutel, ${ }^{34}$ the records of the Exchequer of The Jews in England contain a Latin translation of a Hebrew note with an alternative bearer clause made by one Jew to another as early as 1272 . The translation reads as follows:

29. See Rabinowitz, Some Remarks on the Evasion of the Usary Laws in the Middle Ages, 37 Harv. THEO. REv. 52-53 (1944).

30. See documents quoted in GoLDSCHMIDT, UNIVERSAL-GESCHICHTE DES HANDELsRECHTS 421-26 (1891). (1951).

31. See Rabinowitz, Jewish and Lombard Law, 12 Jewish Soctal Studres 320

32. Baba Metzia 44b.

33. 1 BRUNNER, op. cit. supra note 1 , at 508 .

34. Beutel, supra note 5 , at 823 . 
'Diei le Evesk', Judeus, recognovit per starrum suum, quod tenetur Abrahe, filio Joscei, de Eboraco, in xii 1. sterlingorum, reddendis ei, vel cuicunque presens starrum deferenti, ad festum S. Michaelis anno etc. xxxvi, et si dictum terminum transierit, dicto Abrahe licebit mutuo accipere dictos denarios per manum alicuius Christiani ad usuram, videlicet, pro una libra ii denarios in septimana; it pro toto predicto debito et lucro dictus Diei obligavit dicto Abrahe unam domum . . . dum dictus Abraham vel aliqui assignatorum suorum habeant dictum starrum, dictus Diei non possit alienare (allegare?) aliquam acquietanciam de predicto debito nisi aliquod starrum de acquietancia inde facta per predictum Abraham. . . ."35

A promissory note with an alternative bearer clause, written in Hebrew and dated 1249, is also found in the collection of Hebrew shtaroth published by Davis. ${ }^{36}$

Evidence of the use of the promissory note with the alternative bearer clause by the Jews in the thirteenth century is still more abundant for Spain than for England. This evidence is all the more important, since it comprises a detailed discussion by some of the leading Jewish jurists of Spain of the principles underlying the validity of the promissory note with the alternative bearer clause.

The question of the validity and legal effect of such a note came before Rabbi Meir Abulafia of Toledo, Spain (died in 1244). The portion of the instrument which is quoted by Rabbi Meir reads as follows:

"Reuben and Simeon have constituted us witnesses, with complete kinyan $^{37}$ from now, to the effect that there rests upon them a true obligation by reason of a loan, with credence, to pay eighty gold denars to $R$. Nassi Jacob, or to him who produces this writing, Jew or Gentile, from this day to March of this year, without dispute and without asking for the judicial extension of time. And if Reuben and Simeon, the aforementioned borrowers, fail to pay the said amount to the said lender, or to him who produces this writing, Jew or Gentile, they shall pay all the expenditures that the said $R$. Jacob may incur in collecting the debt from them, or from one of them, up to five gold denars per hundred for

35. 15 Selden Society Publications, Select Pleas, Starrs, and Other RecORDS FROM THE ROLLS OF THE EXCHEQUER OF THE JEWS 65 (Rigg. ed. 1902). $1888)$.

36. Hebrew Deeds of English Jews Before 1290, no. 207 (M. D. Davis ed.

37. "Kinyan (literally: acquisition)-a formality, stimulating an exchange, wherein the party to whom a transfer of property is made, or toward whom an obligation is assumed (or the witnesses to the transaction on his behalf), delivers to the party making the transfer, or assuming the obligation, some object, such as a scarf or a handkerchief, to make the transaction binding and enforceable." THE CODE OF MatMronmes BK. XIII: THE Book of CrvIL LAws 332 (Yale Judaica Series vol. 2, Rabinowitz transl. 1949). 
each month that shall have passed after the said term; and the said borrowers, for themselves and for their heirs after them, have given to the said $R$. Jacob, with regard to every matter that may arise out of this transaction, with regard to these expenditures and with regard to all possible pleas that they might plead against this debt and these expenditures, the credence accorded to two lawful witnesses. ..." 38

There can be not the slightest doubt that the above document represents a true negotiable instrument of the alternative bearer type, which may be enforced by the bearer in his own right, and not just as an agent or representative of the payee named in the instrument. That it was so understood by all concerned becomes obvious from Rabbi Meir's discussion of the instrument.

In the course of his discussion, he states that there was advanced against the validity of the above instrument an argument based upon the following two rules of Jewish law: (1) A conveyance made, or an obligation assumed, in favor of a person yet unborn is invalid, the unborn person lacking capacity to acquire any rights. (2) If any obligation is assumed toward several obligees, one of whom lacks capacity to acquire any rights under the obligation, the obligation is void as to all of the obligees. The description of the obligee in the instrument as "he who produces this instrument," being general, includes within its scope persons yet unborn at the time of the making of the instrument. As to these persons the instrument is invalid under the first rule. Therefore, it was argued, the instrument is void as to all others by virtue of the second rule. Rabbi Meir, however, held the note valid. As to the above argument advanced against its validity, his answer was that the note, being ambiguous, should be so construed as to uphold its validity, and that therefore the phrase "he who produces the instrument" should be construed as referring only to those persons who were in being at the time of the making of the note. It thus appears that the bearer's right to enforce payment was considered to be entirely independent of that of the named payee, and that the bearer was in no way considered the payee's representative.

The question of the legal effect of an alternative bearer clause came also before Rabbi Solomon b. Adreth (1245-1310) who decided that the holder was entitled to demand payment without producing an instrument of assignment. ${ }^{39}$ The holder, Rabbi Solomon held, is on a par with the named obligee. The obligation runs to the one

38. Sefer Or Latzadirm no. 262 (Saloniki 1799).

39. Responsa of R. Solomon B. AdRetr no. 921 (Lemberg 1812). 
as well as to the other. All that is necessary for the holder to qualify as an obligee under the terms of the note is to produce the note.

As a necessary logical consequence of the rationale of the holder's right to sue, Rabbi Solomon, like Rabbi Meir before him, added that where the holder of the note was not yet born at the time the note was made to the original obligee he would be unable to sue on it in his own name. The rule being that one cannot validly bind himself to a person yet unborn, the holder who was born after the note was made could not have been comprehended within the terms of the obligation clause.

It is interesting to contrast the rule stated by Rabbi Meir and Rabbi Solomon relative to the holder who was unborn at the time the note was made with the rule found in fourteenth century French sources that "homme mort n'a porteur de lettres" 40 (a dead man has no bearer of letters). The one rule stands for the proposition that the holder of the note is a principal, and as such he must be in being at the time the obligation is incurred, whereas the other rule stands for the proposition that the holder is an agent of the obligee named in the note and that the death of his principal terminates the agency.

It will be noted that the notes discussed by Rabbi Meir and Rabbi Solomon were of the so-called alternative bearer type, that is, they were payable to a named payee or to the bearer of the instrument. Such a note, while it is in principle freely transferable and does not require an instrument of assignment in order to enable the holder to sue on it, was in some Jewish communities not given the full effect its terms implied. In Toledo, for instance, it was customary to require that the holder produce an instrument of assignment executed by the named obligee. Rabbi Asher b. Jechiel (1250-1327) states in one of his responsa ${ }^{41}$ that the custom is to be respected and followed by the courts. And so custom imposed upon the negotiability of these instruments a restriction which was opposed to principle. But the ingenuity of creditors was quite a match to the conservatism of the courts. Soon the instrument with the pure bearer clause, without a named payee, made its appearance. The courts could not require from the holder an instrument of assignment, executed by the original obligee, since the latter's name did not even appear in the note. They had no choice but to recognize the holder's right to sue on the note without producing an instrument of assignment. A case involving such a note with a pure bearer clause is discussed in another responsum ${ }^{42}$ by Rabbi Asher b. Jechiel, who divides into two parts his argument in favor of the holder's right

40. See 1 BRUNNER, op. cit. supra note 1 , at 517 .

41. Responsa of R. Asmer B. Jechiel c. $68, \S 7$ (1885).

42. $I d$. §9. See also id. \$11. 
to sue. In the first part he says that an obligor may enter into an obligation to a person who is not present at the transaction, either personally or through an appointed agent, by virtue of the principle of $z e k h i a h$, which is to the effect that a right may be validly conferred upon a party through the mediation of another, even in the absence of the party upon whom the right is conferred and without his knowledge. In the second part he says that one may validly bind himself to an unknown person, if that person is ascertainable in the future, and cites the case of King Saul, who bound himself to reward the person who would defeat Goliath.

It seems that the true negotiable note, which was introduced by the Jews before the middle of the thirteenth century and which was based on the principle of zekhiah mentioned above, had a long struggle for recognition against opposition by non-Jewish jurists. It was alien to the principles of the Romanized jurisprudence of the time which adhered to the maxim "alteri nemo stipulari potest." In France in the fourteenth century, as we have seen above, the bearer was looked upon as the agent of the named payee and the death of the payee terminated his agency. ${ }^{43}$ In Spain under the Las Siete Partidas, completed about 1263, a promise in the form of "I promise to give you, or so and so, such-and-such a thing" could not be enforced by the third party. ${ }^{44}$

However, some twenty odd years after the completion of the Las Siete Partidas we find several notes with an alternative bearer clause, written in Spanish and made by non-Jews to Jewish creditors. ${ }^{45}$ These notes contain, in addition to the alternative bearer clause, a clause which indicates that they were patterned after the form of the Jewish promissory note. I am referring to the clause in which the obligor binds his property, movable and landed (bienes muebles et rayces), for the performance of his obligation. The phrase bienes muebles et rayces is most peculiar. One would expect instead bienes muebles et immuebles, movable and immovable being almost a natural dichotomy. How then did it happen that in these documents the phrase bienes muebles et rayces is used? The answer is that this phrase is an exact

43. Brunner states that from the beginning of the thirteenth century French jurisprudence was under the strong influence of Roman law and that it was by reason of this influence that in the fourteenth century the question arose whether the bearer of a promissory note with an alternative bearer clause had an independent right of action against the maker. Bearing in mind that the promissory note with the alternative bearer clause appears in France only towards the end of the thirteenth century, it is difficult to reconcile Brunner's statement with his view that this type of note was an indigenous French product based upon the principles of Germanic law.

1 BRUNNER, op. cit. supra note 1 , at 540 .

44. LAS SteTe Partidas 1095 (Scott transl. 1931).

45. 1 ANUARIO DE HISTORIA DEL DERECHO ESPAÑOL 394 (1924). 
translation of the talmudic metaltelin umekarkein ${ }^{46}$ (movable and landed property) universally found in all Jewish documents of an obligatory nature, in which the debtor binds his property, movable and landed, for the performance of his obligation. ${ }^{47}$

The close dependance of the alternative bearer clause, both in Spain and in France, upon a Jewish model may also be seen in the wording of this clause. In France, it is ou à qui cette lettre portera or apportera $^{48}$ (or to him who will bring this document), while in Spain it is 0 a quien esta carta mostrare ${ }^{49}$ (or to him who will produce this document). The difference in the wording between the French and the Spanish clauses corresponds exactly to the difference in the Hebrew wording between the Jewish documents stemming from England and those stemming from Spain. In the Spanish-Jewish documents it is moși ${ }^{50}$ (he who will produce), while in the Anglo-Jewish documents it is $m e \underline{b} i^{51}$ (he who will bring). Both of these Hebrew terms are used in the Talmud ${ }^{52}$ with respect to legal documents and are certainly not literal translations of the corresponding Spanish and French words. While the Jews of Spain made use of one of these talmudic terms, the Jews of England and France made use of the other, translating as the occasion arose into the vernacular. Hence, the difference between the wording in the Spanish and French alternative bearer clauses.

In addition to the fact that the use of the promissory note with the alternative bearer clause is found among the Jews of Spain and of England at a considerably earlier time than it is found anywhere in Europe among non-Jews, there is other evidence which points to the Jewish origin of this type of note. Some of the special rules of law applicable to the negotiable promissory note seem to be traceable to Jewish law. One of these is the rule concerning protest. Thoel and Brunner are of the opinion that from the very beginning protest was nothing but evidence of presentment, which was necessary in order to put the debtor on a negotiable instrument in default. ${ }^{53}$ Goldschmidt, on the other hand, maintains that protest was originally a

46. See, e.g., Babyzonian Talmud, Baba Bathra 44b.

47. See, e.g., Rab Hai Gaon, supra note 26 , no. 3.

48. See 1 Brunner, op. cit. supra note 1 , at 508-09.

49. See documents cited in note 45 supra.

50. See BAER, op. cit. supra note 20, at 963-64, 979-80, 1003.

51. See Hebrew Deeds of English Jews Before 1290, nos. 28, 93, 207 (M. D. Davis ed. 1888).

52. Mishinah, Gittin 1, 1; Ketuboth 13, 8-9.

53. See 12 Endenann, Handbuch des deutschen Handers-See und WeCHSErRECHT 158 n.15 (1883). 
warning to the debtor that upon default he will be liable to damages and expenses. ${ }^{54}$ The earliest example of protest, cited by both Brunner and Goldschmidt, is a document from Pisa dated 1335.5 The text of this document, in which the payment of damages and expenses is specifically mentioned, seems to support Goldschmidt's view. But the question may still be asked: why was it necessary to warn the debtor of the consequences of his default? The answer seems to be that the requirement of protest is of Jewish origin and is based upon the principle of Jewish law that no penalty is to be imposed upon a person without a previous warning. ${ }^{56}$

In a promissory note with an alternative bearer clause written in Hebrew and made by several Jews to Don Miguel Deca, banker of Pamplona, in the year 1325, there is a postscript in which the obligors state that in case of default they shall be liable, without protest, to a penalty equal to the amount of the principal obligation. ${ }^{57}$ Similar clauses are also contained in two other Hebrew notes from Pamplona dated $1390^{58}$ and $1451,{ }^{59}$ respectively. The fact that as early as 1325 we find already a stipulation for a waiver of protest clearly indicates that the requirement of protest in order to make the obligor liable to a penalty goes beyond that date.

Another rule applicable to negotiable instruments which has a close parallel in Jewish sources is that of grace. Under the law merchant, the debtor on a negotiable instrument is entitled to several days of grace after the due date of the note. ${ }^{60}$ A similar rule prevails in Jewish law and is known as zeman beth-din, which may be rendered somewhat freely as judicial extension of time. Under this rule, a debtor in default may ask the court for an extension of time in order to enable him to raise the money necessary to pay the debt. This rule is stated by Maimonides as follows:

"If the debtor said, 'I am willing to pay, but give me time, so as to enable me to borrow from another or to pledge my property or sell it, and I will bring the money, the court gives him 30 days time. . . ." 61

54. GoLDSCHMTDT, op. cit. supra note 30 , at 457 n.156.

55. 3 Bonaini, Statuti inediti della Citta de Pisa daI XII al XIV secolo 202 n.15 (1870).

56. See Babylonian Talmud, Zebahim 106b-107a.

57. BAER, op. cit. supra note 20 , at 963-64.

58. $I d$. at $979-80$.

59. $I d$. at 1003 .

60. See Goldschmidr, Systen des Handeisrechis 280-81 (4th ed. 1892).

61. The Cone of Matmonides bK. xiII: The Book of Civil Laws 127 n.35 (Yale Judaica Series vol. 2, Rabinowitz transl. 1949). 
Rabbi Asher b. Jechiel ${ }^{62}$ quotes Nachmanides (1205-1270) to the effect that the rule about zeman beth-din is not a rule of strict law but one of grace (rahamim). The similarity between zeman beth-din and the rule of grace in negotiable instruments, together with the other evidence discussed above, is more than suggestive of the Jewish origin of this rule.

62. Commentary of Baba Bathra 10, 25. 